\title{
ISLAMIC PRIMARY SCHOOLS IN THE NETHERLANDS: THE FOUNDING, THE DEBATE, AND THE OUTCOMES ${ }^{1}$
}

\author{
Geert Driessen \\ Driessen Research, The Netherlands, \\ driessenresearch@gmail.com www.geertdriessen.nl
}

Received: 14-11-2020 Revised: 16-12-2020 Accepted: 18-01-2021

\begin{abstract}
At present around 865.000 Muslims live in the Netherlands. In 1988 the first Islamic primary school was founded; now there are 61 with 15,000 students. Islamic education always has been a highly controversial topic in the Netherlands. The debate centers around the question whether the schools contribute to the integration of Muslim youth into Dutch society, or lead to isolation and segregation. This article's goal is to entangle why and how the schools were established, the obstacles met in this process and the resulting heated societal debate, and the schools' attainments in terms of cognitive and noncognitive student achievement. To arrive at these insights a review and analysis of the literature was conducted. The results show that Islamic schools academically achieve relatively well, that is, taking into account their largely socioeconomically disadvantaged student population. Also, they perform best on a pen-and-paper integration test. This does not mean, however, that especially populist and right-wing politicians are convinced now that all Muslim youngsters will accept the Dutch norms and values and will integrate into Dutch society.
\end{abstract}

Keywords: Islamic Education, The Netherlands, Achievement, Integration, Segregation

\section{INTRODUCTION}

It is estimated that there are some 865.000 Muslims in the Netherlands, which is 5 percent of the total Dutch population. ${ }^{2}$ In addition, 23 percent of the Dutch is RomanCatholic, 15 percent Protestant, and 52 percent does not adhere to any religion. ${ }^{3}$ Most Muslims are of Turkish and Moroccan descent, and came to the Netherlands as so-called guest-workers in the 1970s and 1980s or in later years for reasons of family-reunification and family-formation. Since the 1990s, many Muslims have come to the Netherlands as asylumseekers, mainly from countries such as Bosnia, Afghanistan, Iraq, Somalia, and - more recently - Syria. There are also Muslims from the former Dutch colonies Indonesia and Surinam, who came to the Netherlands in the 1950s and in the 1970s and 1980s. ${ }^{4}$

${ }^{1}$ For more detailed information the reader is referred to Driessen and Merry (2006), and Merry and Driessen (2016).

${ }^{2}$ Schmeets, H. De Religieuze Kaart van Nederland, 2010-2015. De Haag: CBS, 2016.

3 CBS. "Kerkelijke Gezindte en Kerkbezoek." Last modified October 7, 2019. https://opendata.cbs.nl/\#/CBS/nl/dataset/37944/table?ts=1604571605657.

4 Butter, E. “Uit Welke Landen Komen Nederlandse Moslims?” Last modified June 14, 2018. http://www.republiekallochtonie.nl/blog/feiten/uit-welke-landen-komen-nederlandse-moslims. 
The Dutch Muslim population constitutes a highly diverse religious group. ${ }^{5}$ They originate from many countries and regions, with each having its own rituals, customs, traditions, and interpretations. About two-thirds of the Dutch Muslims come from Turkey and Morocco; 86 percent of the Turks, and 94 percent of the Moroccans living in the Netherlands adhere to Islam. While 80 percent of the Turkish Muslims are Sunni and 6 percent Alevite, 84 percent of the Moroccan Muslims are Sunni. ${ }^{6}$

The Turkish and Moroccan "guest-workers" (all men) mostly originated from rural areas and started working in industry and agriculture. Most of them had had no or only little education in their home country and did not speak the Dutch language. At first the Dutch government assumed that their stay only would be temporarily and that after a few years they all would return. But this proved to be not the case; they stayed and let their wives and children come over or started new families, many with so-called import-brides from Turkey and Morocco. At present, there are 417,000 first and second generation Turks, and 409,000 Moroccans. $^{7}$

\section{THE FOUNDING OF ISLAMIC SCHOOLS ${ }^{8}$}

When in the 1970s the first Turkish and Moroccan children went to Dutch primary schools, two things soon became apparent to their parents. First, in the regular schools there was an absence of Islamic instruction and possibilities to pray and fast; modern Western clothing regulations did not meet all parents' standards; the children were taught about Darwinian evolution; boys and girls had to engage in sports together; and in biology classes the children were exposed to topics like homosexuality and sexuality. Second, the immigrant children scored significantly lower on achievement tests; had more often to repeat a class; and where transferred to lower types of secondary education than their native-Dutch peers. Many Muslim parents were not happy with this situation.

To address this problematic issue, in some cities Muslim spokesmen (often from mosques) made use of a special feature of the Dutch education system, the constitutional Freedom of Education, ${ }^{9}$ which implies that everyone has the right to found a school and is entitled to full state funding. ${ }^{10}$ There are public and private schools in the Netherlands, the only difference being how they are governed: public schools are administered under the auspices of the municipality, while private schools, mostly religious (or denominational) schools, are managed by a private foundation or association. Public and private schools all

${ }^{5}$ Butter, E., \& Van Oordt, R. (2018). “De 'Islamisering' van Nederland. De Feiten.” Last modified January 19, 2018. http://www.republiekallochtonie.nl/blog/achtergronden/de-islamisering-van-nederland-defeiten\#: : text $=$ Volgens $\% 20$ het $\% 20$ CBS $\% 20$ beschouwt $\% 2012$, percentage $\% 20$ moslims $\% 200 \% 2$ C0 $\% 25$.

${ }^{6}$ Huijnk, W. De Religieuze Beleving van Moslims in Nederland. Diversiteit en Verandering in Beeld. Den Haag: SCP, 2018.

${ }^{7}$ CBS. "Bevolking met Migratieachtergrond." Last modified June 17, 2020.

https://opendata.cbs.nl/statline/\#/CBS/nl/dataset/70787ned/table?fromstatweb.

8 This article focuses on the primary school sector in the Netherlands. At present there are also two secondary Islamic schools, who have received extremely bad press and have been the topic of many governmental investigations. In addition, there are a few Islamic institutes for higher education, who have not all been recognized and financed by the Ministry of Education, and who also are very controversial.

${ }^{9}$ Originally from 1917; the most recent version is Article 23 of the Dutch Constitution of 2008.

10 Driessen, G., \& Merry, M. "Islamic Schools in the Netherlands: Expansion or Marginalization?" Interchange, 37(3), 201-223, 2006. DOI 10.1007/s10780-006-9001-0 
receive the same budget from the Ministry of Education. Unlike public schools, private schools, however, are relatively free to determine what is taught and how, and they may also refuse children, for instance, when they adhere to another religion or to no religion. The Ministry does set quality standards, though, which apply to both public and private schools; these include a minimum number of students (200 within five years), the subjects to be studied, the attainment targets, the language of instruction (Dutch), and the teacher qualifications. ${ }^{11}$

Because of its constitutional Freedom of Education, the Netherlands is confronted with a paradoxical situation. ${ }^{12}$ Whereas since the 1960s the level of secularization has increased considerably and nowadays more than half of the Dutch are not religious anymore, two-thirds of the primary schools still are private-religious schools - at least in name. At present (in 2020) there are 6,174 primary schools with 1,396,575 students; 73 percent of the students are nativeDutch, 3 percent Turkish, and 4 percent Moroccan. Around 32 percent of the schools are public (non-denominational, neutral), 30 percent are Roman-Catholic, also 30 percent are Protestant, and the rest, 8 percent, comprises smaller denominations, such as Islamic, Hindu and Jewish. ${ }^{13}$ There are now 61 Islamic primary schools with around 15,000 students, which is 1 percent of the total number of students. ${ }^{14}$ This is a small number, also relative to the total number of Muslims in the Netherlands, which is 5 percent. Most of the students are of Turkish and Moroccan descent, around three-quarter in total; in addition, smaller groups originate from Surinam, Africa, and the Middle East.

Nearly 74 percent of the Islamic primary schools are member of the central Islamic School Board Organization (ISBO), which is liberal and according to its mission statement aims at emancipating Muslim children. These schools aim at preparing the children for fully functioning and participating in the Dutch society, and do so from the perspective of their own religious and cultural background. The rest of the schools, 26 percent, are founded by local organizations and aim at conserving a specific interpretation (or strand) of the Islamic faith and culture; becoming part of the Dutch society is not their main goal. ${ }^{15}$

A study, carried out nearly two decades ago, found that some 30 percent of the Islamic primary schools were established by Turkish communities. It should be noted that many Turks in the Netherlands still are loyal to the Turkish state, which is of the opinion that Islamic schools are not really necessary because the children can attend Qur'anic education in the mosques (often with imams directly recruited from Turkey). These Islamic schools mostly take a moderate perspective. Around 45 percent of the schools were established by Moroccan communities. The board members of these schools often possess and manifest deeply

11 Merry, M., \& Driessen, G. "On the Right Track? Islamic Schools in the Netherlands after an Era of Turmoil." Race Ethnicity and Education, 19(4) 856-879, 2016. DOI 10.1080/13613324.2014.985586

${ }^{12}$ Dronkers, J. "Islamic Primary Schools in the Netherlands." Journal of School Choice, 10(1), 6-21, 2016. DOI 10.1080/15582159.2015.1131508

${ }^{13}$ CBS. "Onderwijsinstellingen; Grootte, Soort, Levensbeschouwelijke Grondslag." Last modified October 2, 2020. https://www.cbs.nl/nl-nl/cijfers/detail/03753

${ }_{14}$ CBS. "Leerlingen in (Speciaal) Basisonderwijs; Migratieachtergrond, Woonregio." Last modified May 8, 2020. https://www.cbs.nl/nl-nl/cijfers/detail/83295NED

15 Van der Meij, L. "Islamitisch Basisonderwijs in Nederland; Ontstaan, Organisatie en Integratie." Last modified August, $2009 . \quad$ https://www.deisbo.nl/wpcontent/uploads/2010/03/islamitischonderwijsinnederland.pdf 
conservative religious convictions. The rest of the schools, 25 percent, have a mixed schoolboard, coming from diverse ethnic and religious groups. These schools also take a moderate perspective. ${ }^{16}$ This distribution suggests that there are changes regarding the degree of orthodoxy, as a study conducted ten years earlier qualified 85 percent of the schools as conservative or very orthodox. ${ }^{17}$

The establishment of Islamic schools was - and still is - not an easy endeavor. ${ }^{18}$ Without exception, it always takes many years from the first development of ideas till the actual opening of the school. The first Islamic school was established in Rotterdam. The application was submitted in 1980, but it was not until 1988 that the application was approved. There are several reasons for this dragging process. ${ }^{19}$ The applicants were missing necessary organizational and juridical skills; they had insufficient access to external experts and advisors; the authorities involved took a reserved stand, both at the municipal and central level; the applicants regularly met with downright (political) resistance and hardly ever with little official assistance or cooperation. Whether the application was successful or not, often seemed to depend on the perspective from which the establishment was motivated. When the primary goal mentioned in the application was combating the educational disadvantage of Muslim children, the authorities tended to be more accommodating than when the focus was on the religious character of the new school. Nowadays the applicants are much more experienced, especially in juridical terms, and furthermore can rely on the support of ISBO.

\section{FOUR DECADES OF DEBATE}

The Dutch Islamic school landscape is very heterogenous, as is the Muslim population itself, of course. Generally speaking, Islamic schools aim at 1) religious and cultural personality development of the children in the spirit of Islam, and 2) improving the children's academic achievement. For the majority of the parents, the first goal stands central. ${ }^{20}$ Several schools are orthodox, other schools are more or less liberal. Some schools are open to all Islamic denominations, but there are also schools who focus on just one denomination or country of origin. The latter means that most schools are either dominated by Turkish children or by Moroccan children. At some schools boys and girls are separated in the higher classes (in separate class rooms or in separate rows in one classroom) and are (older) girls required to wear headscarves. At all schools there is room for prayer and fasting (the latter mostly for the older children) and the children receive Qur'anic instruction (often by a religious teacher from a mosque), though mostly no more than a few hours per week. In principle, children are socialized from an Islamic perspective, based on Qur'an and Sunna. At some schools chapters

${ }^{16}$ BVD. De Democratische Rechtsorde en Islamitisch Onderwijs. Den Haag: Ministerie van Binnenlandse Zaken en Koninkrijksrelaties, 2002.

${ }^{17}$ Shadid, W., \& Van Koningsveld, P. (Eds.) Islam in Dutch Society. Kampen: Kok Pharos, 1992.

18 Very recently, several applications for establishing new Islamic schools have been turned down by the municipality or Ministry. The official reasons given are that they fear that the schools will not attract and keep enough students, and that existing public and religious schools will lose many students and therefore have to close their doors. The real reason, however, is that there is no public and political support.

${ }^{19}$ Landman, N. Van Mat tot Minaret. De Institutionalisering van de Islam in Nederland. Amsterdam: VU Uitgeverij, 1992.

${ }^{20}$ Denessen, E., Driessen, G., \& Sleegers, P. "Segregation by Choice? A Study of Group-Specific Reasons for School Choice.” Journal of Education Policy, 20(3), 347-368, 2005. DOI 10.1080/02680930500108981 
about reproduction are removed from biology textbooks, the topic of homosexuality is not discussed, and certain issues in history textbooks adapted, for instance about the IsraeliPalestinian conflict, slavery and colonization. Some strict schools remove pictures of live creatures, both human and animal, from textbooks. ${ }^{21}$ In this situation, it is relevant to note that for many years there have been few qualified Muslim teachers available (and, for that matter, not all teachers with a Muslim background want to teach at Islamic schools); some 70 percent of the regular teachers were non-Muslim native-Dutch. It's only recently that more and more teachers are of Turkish and Moroccan descent and Muslim, now some 40 percent. In several schools the board has appointed a policy officer, a Muslim who is a member of the board or a trustee (regularly family or friends) who watches over the religious aspects of the education. $^{22}$

The establishment of Islamic schools has not only led (and still leads) to heated discussions in Dutch society at large, often in municipalities and by leading national politicians, but also within the Muslim community itself. Firstly between those who are in favor of Islamic schools and those who oppose to them, and secondly also between adherents of different strands of Islam. Many were of the opinion that the establishment of Islamic schools was more ideologically and politically motivated than religiously. ${ }^{23}$ They feared especially traditional fundamentalist groups would make use of them, which - at the time at least - was confirmed by the fact that in the 1990s most schools were very orthodox. ${ }^{24}$ The main objections against Islamic schools were that they would lead to inequality, isolation, social exclusion and separation ("self-segregation") of a future Muslim generation instead of full participation and integration into Dutch society, and that children attending Islamic schools therefore would not acculturate to the Dutch liberal democratic norms and values. ${ }^{25}$ The debate reached a high point after the $9 / 11$ terrorist attacks (in 2001), the staggering rise and influence of the Dutch populistic right-wing politician Pim Fortuyn, whose main theme

${ }^{21}$ Merry, M., \& Driessen, G. "On the Right Track? Islamic Schools in the Netherlands after an Era of Turmoil." Race Ethnicity and Education, 19(4) 856-879, 2016. DOI 10.1080/13613324.2014.985586

22 Driessen, G., \& Merry, M. "Islamic Schools in the Netherlands: Expansion or Marginalization?" Interchange, 37(3), 201-223, 2006. DOI 10.1007/s10780-006-9001-0

Van der Meij, L. (2009). "Islamitisch Basisonderwijs in Nederland; Ontstaan, Organisatie en Integratie." Last modified August, $2009 . \quad \underline{\text { htps://www.deisbo.nl/wp- }}$ content/uploads/2010/03/islamitischonderwijsinnederland.pdf

${ }^{23}$ Kabdan, R. “Op Weg naar Maatschappelijke Spanningen op Religieuze Gronden.” Vernieuwing,

51(9), 4-8, 1992.

There also is recent proof for this. After the failed coup in Turkey in 2016, president Erdogan accused Fethullah Gülen of being the instigator. This led to two sections within the by Turks dominated Islamic schools in the Netherlands. In a reaction, many hundreds of students and tens of teachers left the so-called Gülen schools.

${ }^{24}$ Shadid, W., \& Van Koningsveld, P. (Eds.) Islam in Dutch Society. Kampen: Kok Pharos, 1992.

25 Phalet, K., \& Ter Wal, J. (Eds.). Moslim in Nederland. Een Onderzoek naar de Religieuze Betrok.kenheid van Turken en Marokkanen. Den Haag: SCP, 2004.

Van der Meij, L. (2009). "Islamitisch Basisonderwijs in Nederland; Ontstaan, Organisatie en Integratie." Last modified August, $2009 . \quad$ https://www.deisbo.nl/wpcontent/uploads/2010/03/islamitischonderwijsinnederland.pdf

It is striking that there are also 165 orthodox-reformed Protestant primary schools in the Netherlands, who in many respects keep to the same principles as Islamic schools but are hardly ever questioned about this. In case there is some debate, they are always defended by (Christian) politicians and the Minister for Education referring to the Freedom of Education. 
during the 2002 elections was (anti-)immigration and integration, and the murder of the Dutch film director Theo van Gogh by a radicalized Muslim (in 2004). In a climate of overt distrust, Islam and the Islamic schools came more and more under scrutiny and attack. The key questions posed to Muslims seemed to be: Are you for or against the modern, democratic, emancipated and highly secularized Dutch society with much personal freedom (and responsibilities) and its associated norms and values? Do you want to fully integrate and participate in Dutch society, or do you want to live in a parallel society, outside the Dutch society or even work against Dutch society?

\section{THE OUTCOMES}

\section{The Schools' Functioning}

This climate of distrust led to a series of rather intensive examinations by the Dutch government, often at the request of Parliament, carried out by the Inspectorate of Education and the National Security Service. Examinations like this are unprecedented in the Netherlands, as no other religious school denomination has been the target of this kind of scrutiny before. ${ }^{26}$ Among other things, these studies focused on the quality of the schools in terms of educational output, i.e. attainment, and - more and more - on the fundamental question whether the schools were really preparing their students for living in a liberal democratic society or not. What follows is an overview of the most important reports, concentrating on the integration aspect.

In 1989, when there were 6 Islamic schools, the Inspectorate of Education ${ }^{27}$ conducted an investigation into their functioning and possibly fundamentalist character. The conclusions were rather positive: though the school work plan did not always completely meet the legal requirements, all teachers had had an adequate teacher training (with the exception of the religious instruction teachers); the language usually spoken was Dutch (again, not by all religious instruction teachers); and the curriculum largely did not deviate from that of the average primary school and was aimed at the children's functioning in Dutch education and society.

In 1998, the National Security Service ${ }^{28}$ wrote a report on political Islam in the Netherlands, focusing on the interference of foreign powers (e.g., Iran and Saudi-Arabia) and political-Islamic organizations with the contents of education. The results showed that some Islamic schools received substantial donations from the Al-Waqf al-Islami organization, which propagates a very extremist political-religious worldview and is intolerant towards liberal Muslims, Jews, and Christians. It was hypothesized that the expected increasing influence of such organizations might lead to polarization and disruption of the process of integration.

${ }^{26}$ Van der Meij, L. "Islamitisch Basisonderwijs in Nederland; Ontstaan, Organisatie en Integratie." Last modified August, 2009. https://www.deisbo.nl/wpcontent/uploads/2010/03/islamitischonderwijsinnederland.pdf

${ }^{27}$ Inspectie van het Onderwijs. Nader Onderzoek naar het Functioneren van de Islamitische Scholen. Zoetermeer: Ministerie van Onderwijs en Wetenschappen, 1989.

Inspectie van het Onderwijs. Onderzoek naar het Fundamentalistische Karakter van Vier per 1 Augustus 1989 Opgerichte Islamitische Scholen. Zoetermeer: Ministerie van Onderwijs en Wetenschappen, 1990.

${ }^{28}$ BVD. De Politieke Islam in Nederland. Den Haag: Ministerie van Binnenlandse Zaken, 1998. 
In 1999, the Inspectorate of Education ${ }^{29}$ conducted yet another study and showed that because of differences between Western and Islamic norms and values, there were frequently tensions between the schools' boards, the principals and the teachers (who mostly were not Muslim). It was striking that on 11 educational quality standards, the Islamic schools outperformed schools with a comparable (i.e. disadvantaged) student population, and on 4 standards they scored even better than the average school. Islamic schools scored relatively low with regard to pedagogical climate and quality of teaching (especially stimulating and challenging students); they scored relatively high regarding educational content, planning and use of instruction time, and efficiency of classroom organization. To put things into perspective, the Inspectorate pointed to the fact, however, that the differences among the Islamic schools were far greater than those between the Islamic and non-Islamic schools.

In 2002, the National Security Service ${ }^{30}$ conducted a study focusing on two questions: is Islamic education potentially threatening to democratic norms, and is there evidence of foreign infiltration? The study reported that 20 percent of the schools received financial support or had regular contact with foreign Islamic organizations such as the Saudi al-Waqf alIslami, the Libyan World Islamic Call Society and the Turkish Diyanet. Although no evidence for overt foreign influence was found, the study did find that several individual school board members were quite orthodox and sympathetic to the violent aims of radical groups, such as Hamas and the Muslim Brotherhood. It was concluded that from a democratic-judicial perspective there were hardly any problems ( 80 percent) at the majority of the Islamic schools.

In 2002, the Education Inspectorate ${ }^{31}$ concluded that more than 90 percent of the Islamic schools were satisfactorily assisting the children in their integration process. Almost all schools had an open attitude towards Dutch society and contributed to creating conditions for social cohesion; attending an Islamic school did not hinder integration. The study also revealed, however, that there still was no adequate religious education method specifically geared at the Dutch context. As a consequence several schools imported and translated very conservative and culturally irrelevant material from traditionally Islamic countries.

In a follow-up study in $2003^{32}$, the Inspectorate's rather positive conclusions regarding integration were quite similar. In addition, it was found that Islamic schools were doing acceptably well, that is, taking into account their largely disadvantaged student population. Nevertheless, the Inspectorate again pointed to the failing didactic quality of religious education, and also to insufficiently implemented quality controls.

In another investigation by the Inspectorate in $2008^{33}$ the focus was on administration and management. This study revealed irregularities in not less than three quarters of the school boards. Even more amazingly, 86 percent of the Islamic schools showed evidence of

\footnotetext{
${ }^{29}$ Inspectie van het Onderwijs. Islamitische Basisscholen in Nederland. Utrecht: Inspectie van het Onderwijs, 1999.

${ }^{30}$ BVD. De Democratische Rechtsorde en Islamitisch Onderwijs. Den Haag: Ministerie van Binnenlandse Zaken en Koninkrijksrelaties, 2002.

${ }^{31}$ Inspectie van het Onderwijs. Islamitische Scholen en Sociale Cohesie. Utrecht: Inspectie van het

Onderwijs, 2002.

32 Inspectie van het Onderwijs. Islamitische Scholen Nader Onderzocht. Utrecht: Inspectie van het

Onderwijs, 2003.

33 Inspectie van het Onderwijs. Bestuurlijke Praktijken in het Islamitische Onderwijs. Utrecht: Inspectie van het Onderwijs, 2008.
} 
fraud, while for the whole education sector this is 2 percent. At almost half of the schools, quality controls regarding the schooling provided and the students' achievement levels were found to be weak or very weak. Compared to other schools with a similar disadvantaged student population Islamic schools were achieving somewhat better, but still lagged far behind the average Dutch school.

To summarize the findings from the various investigations, it can be concluded that, apart from a number of relatively positive remarks with regard to the students' integration and attainment, there were several problematic or even worrisome issues. There were contacts with foreign political organizations, who donated large sums of money to the school boards. Several school boards were quite orthodox and not liberal. Fraud was revealed on an unheard of large scale in the Dutch education sector. Quality controls were often lacking. An adequate religious instruction method geared to the Dutch context was still not available.

\section{THE STUDENTS' ATTAINMENT}

Right from the beginning, Islamic education has been a highly controversial topic, with the mass media playing a significant role. In the course of years, the attitude of the general Dutch population, politicians, and media has shifted from being open-minded and accommodating to critical and even manifestly negative. ${ }^{34}$ As a reaction to the Inspectorate's and Security Service's severe criticism and the mounting bad press, the umbrella organization ISBO, which represented most of the Islamic schools (although not the orthodox ones), started to undertake various measures under the banner of Quality Improvement Islamic Schools in $2008 .{ }^{35}$ Until then the focus had been on establishing more schools, i.e. on quantity, but this shifted to quality, professionality and stability, particularly improving the administration and management, the education and the achievement of the existing schools. An evaluation of this improvement process showed that important steps had been taken and that the overall quality level had been raised, but this study also showed that there still were many points that should be improved, for instance with regard to parental participation, cooperation, and communication. ${ }^{36}$ ISBO already had developed an official Islamic course book for religious instruction, which was published in 2006. Because this was required by the Ministry, in later years ISBO also developed a method for early adolescence, which provides information on sexuality and was published in 2015. This method met with very much resistance in 2019, however, because, among other things, it condemned homosexuals and transgendered people. Therefore, ISBO then decided to adjust the relevant passages in this textbook.

What follows is a summary of the most recent studies into the students' attainment. ${ }^{37}$ One of the two main goals of founding Islamic schools was to improve the students' overall

\footnotetext{
34 Merry, M., \& Driessen, G. "On the Right Track? Islamic Schools in the Netherlands after an Era of Turmoil.” Race Ethnicity and Education, 19(4) 856-879, 2016. DOI 10.1080/13613324.2014.985586

Ter Avest, K., \& Rietveld-Van Wingerden, M. "Half a Century of Islamic Education in Dutch Schools." British Journal of Religious Education, 39(3), 293-302, 2017. DOI 10.1080/01416200.2015.1128391

35 Altuntas, Y. "ISBO: Voorlopig Geen Nieuwe Islamscholen." De Volkskrant, December 1, 2008.

36 Van Velzen, B., \& De Vijlder, F. Een Verleden Heb Je, De Toekomst Moet Je Maken. Amersfoort: ISBO, 2012.

${ }^{37}$ It is remarkable that, apart from the global monitoring of all schools by the Inspectorate of Education, there has been no scientific investigation into the performance of students at Islamic schools financed by the
} 
performance, not only in cognitive terms (e.g. literacy and numeracy), but also in noncognitive terms (e.g. attitudes and behavior). To validly interpret the level of attainment, it is critical to keep in mind the disadvantaged home situation of most of the students and adjust their attainment scores for this "handicap". ${ }^{38}$ At the same time it is relevant to point to an important compensatory feature of the primary school funding system. As part of the national Educational Disadvantage Policy, additional funding is allocated to schools based on the socio-ethnic composition of their student population. ${ }^{39}$ The policy's aim is to prevent and combat educational disadvantage resulting from factors in the students' home situation; the main indicators for this are a low social milieu (parental education and profession) and immigrant origin. Because Islamic schools are predominantly attended by students from disadvantaged immigrant backgrounds, they may receive up to almost twice as much extra financial resources as non-disadvantaged schools. Schools are free to use this extra money, for instance, for class size reduction or individual student support.

In a large-scale nationwide study, Merry and Driessen (2016) ${ }^{40}$ analyzed the scores on various cognitive and non-cognitive output measures. In their analyses they compared three categories of schools: 1) Islamic schools; 2) comparable schools, i.e. schools with a similar, mostly disadvantaged student population; and 3) the average school. The data they used were collected in 2011 in grades 2, 5 and 8 of 550 primary schools and 38,000 students. Language and Math. The analyses revealed that from grade 2 to grade 8 , Islamic schools are gradually achieving better for both language and math than comparable schools. Especially in grade 8, the final grade, Islamic schools are achieving much better in math than comparable schools. A similar positive development can be noticed from the comparison with the average school. In grade 8 the difference practically disappears in math, though the students at Islamic schools still considerably lag behind in language achievement. Motivation. Two important factors related to the students' motivation to learn are Self-efficacy and Task-motivation. The analyses revealed that while in grade 5 students at Islamic schools do not differ from those at comparable schools, grade 8 students at Islamic schools score somewhat higher. The comparison with students at the average Dutch school is remarkable. Not only in grade 5 but even more so in grade 8, students at Islamic schools score much higher than their peers at the average school. Citizenship. As of 2004, all primary schools (but specifically Islamic schools) are required to give attention to the subject of citizenship education and integration. In the analyses, four dimensions were discerned: Reflection, Skills, Attitudes, and Knowledge. The most striking finding was that for the first three dimensions students at Islamic schools score considerably higher than their peers at comparable schools, and still higher than those at the average school. With respect to the Knowledge dimension (i.e., knowing, understanding, having insight), students at Islamic schools score approximately the same as students at

\footnotetext{
Ministry of Education. The Ministry is very reluctant to subsidize such studies because the chance of being accused of discrimination.

38 Driessen, G., \& Merry, M. “Trends in Educational Disadvantage in Dutch Primary School.” Educational Review, 66(3), 276-292, 2014. DOI 10.1080/00131911.2013.771146

${ }^{39}$ Driessen, G. "The Validity of Educational Disadvantage Policy Indicators." Educational Policy Analysis and Strategic Research, 12(2), 93-108, 2017.

40 Merry, M., \& Driessen, G. "On the Right Track? Islamic Schools in the Netherlands after an Era of Turmoil. Race Ethnicity and Education, 19(4) 856-879, 2016. DOI 10.1080/13613324.2014.985586
} 
comparable schools, though significantly lower than students at the average school. These findings are remarkable, because it often is assumed that Islamic schools are mainly focusing on their own closed Muslim community and much less or even not on their host country (here: The Netherlands). The results are proof that the Islamic schools have an open eye for the central societal tasks underlying the four dimensions discerned: acting democratically; acting in a socially responsible manner; dealing with conflicts; and dealing with differences. School leavers' test. In the final grade (8), students completed the so-called Primary school leavers' test, which covers language, math, and study skills. In addition to three subtest scores a total test score was available. Students at Islamic schools perform better than students at comparable schools for math, study skills and the test as a whole, but achieve lower than their peers at the average school for language, study skills, and the test as a whole. Secondary education recommendation. In the final grade of primary school students receive a recommendation as to their most appropriate type of secondary education. Students at Islamic schools get a higher recommendation than students at comparable schools, but a lower recommendation than their peers at the average school.

In another study, Driessen, Agirdag and Merry (2016) ${ }^{41}$ analyzed a representative sample of 386 schools and 27,457 students in grades 2, 5 and 8 of 143 Public, 101 Protestant, 125 Catholic and 17 Islamic schools; the data were collected in 2011. The focus was on denominational cognitive and non-cognitive output differences (the same as in the Driessen and Merry (2016) ${ }^{42}$ study), using advanced multilevel analysis techniques. To correctly appreciate the schools' output, two measures were calculated: the gross output and the net output. To arrive at the net output the gross output (or "raw" scores) was corrected for by several factors at the level of the students and the schools (parental educational level and country of origin). With regard to the gross effects, the analyses revealed that Protestant schools perform slightly better than public schools, definitely regarding the cognitive measures (e.g. Language and Math). With regard to the non-cognitive measures (Self-Efficacy and Task Motivation and Citizenship Reflection and Skills) they perform somewhat worse. In terms of academic achievement, Catholic schools do not differ much from public schools. Islamic schools perform the worst on nearly all cognitive measures. It is striking, however, that on almost all non-cognitive measures (with the exception of Citizenship Knowledge) they perform better or even much better than the other religious schools. When next looking at the net effects, the analyses show that of the 30 significant gross effects only 2 net effects remain significant. It is remarkable that after correction for social and ethnic differences in student and school backgrounds, Islamic schools even achieve better (though only in one case significantly) than the other religious schools on nearly all output measures. Thus, although Islamic schools in an absolute sense perform lowest on all cognitive measurements, they succeed in raising their students' output more than the other religious schools. With regard to the non-cognitive measurements (except Citizenship Knowledge) they already score highest in an absolute sense. These findings can be interpreted as that the Islamic school sector has the

${ }^{41}$ Driessen, G., Agirdag, O., \& Merry, M. "The Gross and Net Effects of Primary School Denomination on Pupil Performance.” Educational Review, 68(4), 466-480, 2016. DOI 10.1080/00131911.2015.1135880

42 Merry, M., \& Driessen, G. "On the Right Track? Islamic Schools in the Netherlands after an Era of Turmoil." Race Ethnicity and Education, 19(4) 856-879, 2016. DOI 10.1080/13613324.2014.985586 
highest positive "added value" power of all denominations. Hence, the Islamic schools succeed in reversing their worrisome position from being the most disadvantaged sector (gross) to the most advantaged sector (net).

In a series of annual studies, Dronkers $(2014)^{43}$ also analyzed the results on the Primary school leavers' test. Unlike the studies cited earlier, that worked with samples, he had data of the total population of Dutch schools at his disposal. He also focused on the value-added power of the various public and denominational school sectors. This added value was computed by correcting the gross test scores for a number of social and ethnic disadvantage indicators at the level of the students and the schools, which resulted in the net denominational effect. He firstly computed separate effects for a series of successive years, which showed that Islamic schools did surprisingly well, if not the best. To check whether these findings were stable over a number of years, he computed the average added value for 2012, 2013 and 2014. The results showed that initially the Islamic schools performed worst of all twelve denominations (including Public), which is the gross effect. However, after correcting for the disadvantage indicators the analyses revealed that, but for the (only 6) Hindu schools, the Islamic schools had the highest positive added value. Dronkers also pointed to the fact that for the Islamic sector the standard deviation of the value added score was rather high, which means that there is much variation in this sector's scores, or, in other words, on the one hand there are quite some Islamic schools with a negative added value, and on the other hand many schools with a high positive added value.

For the next five consecutive years 2015-2019, De Regt and Bunskoek (2019) ${ }^{44}$ repeated Dronkers' (2014) ${ }^{45}$ analyses, though using even more sophisticated data and techniques. From their analyses they concluded that for each of the five years (2015, 2016, 2017, 2018 and 2019) the Islamic schools in terms of added value performed best of all denominations.

\section{CONCLUSION}

Islamic schools in the Netherlands were established for two reasons: they wanted to ensure an education in the spirit of Islam, and optimal academic achievement for Muslim children. Right from the start they met with distrust, controversy, aversion and opposition. The heated debates that followed mostly boil down to the fact that a large part of the nativeDutch population, including many leading politicians, who mostly are not religious, fear that separate Islamic schools will not lead to the desired integration and participation, but instead to segregation and isolation. This is not only the opinion of the native-Dutch, however, but also that of many immigrants and even Muslims themselves. What is more, the Muslim community who is in favor of separate Islamic schools is strongly divided in itself, depending on, for instance, immigrant country and interpretation of Islam. In the course of years, the

${ }^{43}$ Dronkers, J. CITO Scores en Denominatie, Onderwijsvisie en Schoolbesturen. Maastricht: Universiteit Maastricht, 2014.

${ }^{44}$ De Regt, K., \& Bunskoek, J. “Zeeuwse Basisscholen Scoren het Beste op de Eindtoets.” Last modified February 18, 2019. https://www.rtlnieuws.nl/nieuws/artikel/4603151/scholenonderzoek-rtl-nieuws-eindtoetscito-2018-iep-route-8

45 Dronkers, J. CITO Scores en Denominatie, Onderwijsvisie en Schoolbesturen. Maastricht: Universiteit Maastricht, 2014. 
worries have been amplified by the continuous terrorist attacks of radical and extremist Muslims in the Netherlands and abroad.

As a result of this highly controversial climate, the Dutch government initiated a number of investigations focusing on the question whether Islamic schools really contribute to their students' integration and succeed in raising their achievement. Regarding the former, the studies showed that, apart from a number of relatively positive remarks with regard to the students' integration and attainment, there were several problematic or even worrisome issues: contacts with foreign political organizations; schoolboards that were quite orthodox and illiberal; large-scale fraud among school boards; a lack of quality controls; and inadequate religious instruction methods. As a response, the Islamic School Board Organization, that represents the liberal schools but not the orthodox schools, initiated a quality improvement trajectory, focusing on professionality and stability.

A large-scale study showed that with respect to cognitive outcome measures, Islamic schools performed better than schools with a comparable similar (i.e. disadvantaged) student population, but still lagged far behind the average Dutch school. Regarding non-cognitive outcome measures, Islamic schools scored higher than both comparable schools and the average school. A striking finding was that Islamic schools performed better than the other schools on an integration test. In a series of studies that compared the Islamic school sector to the public and other denominational sectors, the results showed that initially the Islamic schools performed worst, but once corrected for the fact that Islamic schools mostly cater for children from disadvantaged families, it appeared that they scored highest.

Notwithstanding this relative success, the Islamic schools, after thirty years, still do not achieve as well as the average Dutch school. Despite this success, many politicians (especially populist and right-wing ones) continue to express grave concerns about the functioning and effectiveness of Islamic schools, specifically pointing to the perceived lack of integration of many Muslim youngsters. Although the debate around Islamic primary schools has become less heated the last decade, history demonstrates that it does not need much to start all over again.

\section{REFERENCES}

Altuntas, Y. "ISBO: Voorlopig Geen Nieuwe Islamscholen." De Volkskrant, December 1, 2008.

BVD. De Democratische Rechtsorde en Islamitisch Onderwijs. Den Haag: Ministerie van Binnenlandse Zaken en Koninkrijksrelaties, 2002.

BVD. De Politieke Islam in Nederland. Den Haag: Ministerie van Binnenlandse Zaken, 1998.

Butter, E., \& Van Oordt, R. "De 'Islamisering' van Nederland. De Feiten." Last modified January 19, 2018. http://www.republiekallochtonie.nl/blog/achtergronden/deislamisering-van-nederland-de-

feiten\#: :text=Volgens $\% 20$ het $\% 20$ CBS $\% 20$ beschouwt $\% 2012$,percentage $\% 20$ moslim s $\% 200 \% 2 \mathrm{C} 0 \% 25$.

Butter, E. "Uit Welke Landen Komen Nederlandse Moslims?” Last modified June 14, 2018. http://www.republiekallochtonie.nl/blog/feiten/uit-welke-landen-komennederlandse-moslims. 
CBS. “Kerkelijke Gezindte en Kerkbezoek." Last modified October 7, 2019. https://opendata.cbs.nl/\#/CBS/nl/dataset/37944/table?ts=1604571605657.

CBS. "Leerlingen in (Speciaal) Basisonderwijs; Migratieachtergrond, Woonregio." Last modified May 8, 2020. https://www.cbs.nl/nl-nl/cijfers/detail/83295NED.

CBS. "Bevolking met Migratieachtergrond." Last modified June 17, 2020. https://opendata.cbs.nl/statline/\#/CBS/nl/dataset/70787ned/table?fromstatweb.

CBS. "Onderwijsinstellingen; Grootte, Soort, Levensbeschouwelijke Grondslag." Last modified October 2, 2020. https://www.cbs.nl/nl-nl/cijfers/detail/03753

De Regt, K, \& Bunskoek, J. “Zeeuwse Basisscholen Scoren het Beste op de Eindtoets.” Last modified February

18 , 2019. https://www.rtlnieuws.nl/nieuws/artikel/4603151/scholenonderzoek-rtl-nieuwseindtoets-cito-2018-iep-route-8

Denessen, E., Driessen, G., \& Sleegers, P. "Segregation by Choice? A Study of Group-Specific Reasons for School Choice." Journal of Education Policy, 20(3), 347-368, 2005. DOI 10.1080/02680930500108981

Driessen, G. "The Validity of Educational Disadvantage Policy Indicators.” Educational Policy Analysis and Strategic Research, 12(2), 93-108, 2017.

Driessen, G., \& Merry, M. "Islamic Schools in the Netherlands: Expansion or Marginalization?” Interchange, 37(3), 201-223, 2006. DOI 10.1007/s10780-006-9001-0

Driessen, G., \& Merry, M. "Trends in Educational Disadvantage in Dutch Primary School." Educational Review, 66(3), 276-292, 2014. DOI 10.1080/00131911.2013.771146

Driessen, G., Agirdag, O., \& Merry, M. "The Gross and Net Effects of Primary School Denomination on Pupil Performance." Educational Review, 68(4), 466-480, 2016. DOI 10.1080/00131911.2015.1135880

Dronkers, J. CITO Scores en Denominatie, Onderwijsvisie en Schoolbesturen. Maastricht: Universiteit Maastricht, 2014.

Dronkers, J. "Islamic Primary Schools in the Netherlands." Journal of School Choice, 10(1), 6-21, 2016. DOI 10.1080/15582159.2015.1131508

Huijnk, W. De Religienze Beleving van Moslims in Nederland. Diversiteit en Verandering in Beeld. Den Haag: SCP, 2018.

Inspectie van het Onderwijs. Nader Onderzoek naar het Functioneren van de Islamitische Scholen. Zoetermeer: Ministerie van Onderwijs en Wetenschappen, 1989.

Inspectie van het Onderwijs. Onderzoek naar het Fundamentalistische Karakter van Vier per 1 Augustus 1989 Opgerichte Islamitische Scholen. Zoetermeer: Ministerie van Onderwijs en Wetenschappen, 1990.

Inspectie van het Onderwijs. Islamitische Basisscholen in Nederland. Utrecht: Inspectie van het Onderwijs, 1999.

Inspectie van het Onderwijs. Islamitische Scholen en Sociale Cohesie. Utrecht: Inspectie van het Onderwijs, 2002.

Inspectie van het Onderwijs. Islamitische Scholen Nader Onderzocht. Utrecht: Inspectie van het Onderwijs, 2003. 
Inspectie van het Onderwijs. Bestuurlijke Praktijken in Het Islamitische Onderwijs. Utrecht: Inspectie van het Onderwijs, 2008.

Kabdan, R. "Op Weg naar Maatschappelijke Spanningen op Religieuze Gronden." Vernieuwing, 51(9), 4-8, 1992.

Landman, N. Van Mat tot Minaret. De Institutionalisering van de Islam in Nederland. Amsterdam: VU Uitgeverij, 1992.

Merry, M., \& Driessen, G. "On the Right Track? Islamic Schools in the Netherlands after an Era of Turmoil." Race Ethnicity and Education, 19(4) 856-879, 2016. DOI 10.1080/13613324.2014.985586

Phalet, K., \& Ter Wal, J. (Eds.). Moslim in Nederland. Een Onderzoek naar de Religieuze Betrokkenheid van Turken en Marokkanen. Den Haag: SCP, 2004.

Schmeets, H. De Religieuze Kaart van Nederland, 2010-2015. De Haag: CBS, 2016.

Shadid, W., \& Van Koningsveld, P. (Eds.) Islam in Dutch Society. Kampen: Kok Pharos, 1992.

Ter Avest, K., \& Rietveld-Van Wingerden, M. "Half a Century of Islamic Education in Dutch Schools." British Journal of Religious Education, 39(3), 293-302, 2017. DOI 10.1080/01416200.2015.1128391

Van der Meij, L. "Islamitisch Basisonderwijs in Nederland; Ontstaan, Organisatie en Integratie." Last modified August, 2009. https://www.deisbo.nl/wpcontent/uploads/2010/03/islamitischonderwijsinnederland.pdf

Van Oordt, R., \& Butter, E. "Hoe Zit het Nu Eigenlijk met de Groei van Islamitisch Onderwijs?" Last modified December 13, 2019. http://www.republiekallochtonie.nl/blog/achtergronden/hoe-zit-het-nu-eigenlijkmet-de-groei-van-islamitisch-onderwijs

Van Velzen, B., \& De Vijlder, F. Een Verleden Heb Je, De Toekomst Moet Je Maken. Amersfoort: ISBO, 2012. 